ORIGINAL ARTICLE

\title{
Extracutaneous infantile haemangioma is also Glut1 positive
}

\section{R M Drut, R Drut}

J Clin Pathol 2004;57:1197-1200. doi: 10.1136/icp.2003.012682

See end of article for authors' affiliations

.....................

Correspondence to:

Dr R M Drut, Department of Pathology, Hospital de Niños "Superiora Sor María Ludovica", 1900, La Plata, Argentina; patologi@netverk.com.ar

Accepted for publication 12 February 2004

\begin{abstract}
Aim: To investigate whether extracutaneous infantile haemangioma-like tumours are immunohistochemically similar to cutaneous infantile haemangiomas.

Methods: Mammary, salivary gland, liver (one each), and placental (two cases) capillary haemangiomas and typical examples of cutaneous (eight cases) infantile haemangioma were investigated immunohistochemically for $\alpha$ smooth muscle actin and Glut1, a proposed marker for the skin localised lesion. Positive internal controls included red blood cells, perineurium, trophoblast, and endothelial cells of the placental capillaries. Extralesional vessel endothelium acted as a negative control (except in the placenta). The liver haemangioma and both chorioangiomas presented in patients with Beckwith-Wiedemann syndrome.

Results: The endothelial cells of all the vascular lesions were Glutl positive. These were consistently surrounded by a rim of $\alpha$ smooth muscle actin positive pericytic cells. Controls reacted appropriately.

Conclusions: All infantile haemangiomas were immunohistochemically positive for Glut1: expression of this molecule was not limited to infantile haemangiomas of the skin. These tumours comprise proliferations of both endothelial and pericytic cells. The association with Beckwith-Wiedemann syndrome may provide a clue to the molecular genetics of infantile haemangioma.
\end{abstract}

l: $\mathrm{n}$ recent years, there have been important advances in the conceptual understanding of vascular tumours and malformations of the skin in newborns, infants, and children. As a result of these investigations, Glutl has emerged as a marker for an unusual vascular tumour, namely infantile haemangioma (IH). ${ }^{1}$ Other vascular tumours and malformations do not express such strong and diffuse reactivity for Glutl as IH. ${ }^{1} \mathrm{IH}$ vessels share endothelial immunoreactivity for Glutl, merosin, Lewis-Y, and $\gamma$ Fc receptor II with the capillaries of the placenta. ${ }^{2}$ This fact has suggested a possible pathogenesis of the lesion. North et al have proposed that vascular precursor cells (angioblasts) might aberrantly differentiate towards the microvascular phenotype within fetal tissues at sites of haemangioma development, as a result of either somatic mutation or abnormal local inductive influences. An alternative hypothesis suggests that normal endothelial cells or genetically altered clones of these cells might embolise from the placenta to the fetal tissues ( $P$ North, H Kozakewich H. Vascular malformations and tumors in children. Society for Pediatrc Pathology. Washington, DC: Annual Meeting Workshop Handout, March 2003:22-3). ${ }^{2}$

\section{"Glut1 has emerged as a marker for an unusual vascular tumour, namely infantile haemangioma"}

Our present investigation was designed to determine whether haemangiomatous tumours that share phenotypic features with cutaneous $\mathrm{IH}$, but which have developed at other sites, express immunoreactivity for Glutl, thus indicating a possible similar histogenesis.

\section{METHODS}

Examples of cutaneous IH (eight cases), chorioangioma (two cases), and liver, mammary gland, and submaxillary gland haemangioma (one each) sharing histological features with cutaneous IH were retrieved from the files of the department of pathology, Hospital de Niños "Superiora Sor María Ludovica", Argentina. Table 1 presents the clinical data.
Immunohistochemistry for Glutl was performed as follows: dewaxed tissue sections were heat treated twice in $10 \mathrm{mM}$ citrate buffer in a microwave oven at maximum power for 10 minutes each, allowed to cool at room tempertaure for 15 minutes, and rinsed in PBS. Sections were incubated with normal swine serum for 10 minutes, followed by rabbit antiGlut l (Dako, Carpinteria, California, USA; A3536, lot 117; 1/300 dilution) for one hour. Detection was performed with the LSAB2 system (Dako).

Endothelial cells of local vessels outside the tumours were used as internal negative controls and red blood cells, basal keratinocytes, perineurium, and microvillous and basal membranes of the syncytiotrophoblast were used as positive internal controls. A liver haemangioendothelioma type I and normal fetal ( 11 weeks of gestational age) brain tissue were used as endothelial negative and positive controls, respectively.

All the cases were also submitted to immunostaining for $\alpha$ smooth muscle actin (Dako; N1584, lot 021-4; prediluted) and AE1/AE3 cytokeratin (Dako; N1590, lot 011-4; prediluted) to define the smooth muscle and the ductal epithelial components of each tumour, respectively.

\section{RESULTS}

Skin IH showed numerous vessels with some variations in its structure according to the site of the lesion. In general, central areas appeared more cellular and contained small vessels with plump endothelium surrounded by plump multilayered pericytic cells. At the periphery of the lesions, the small vessels presented larger lumina, less prominent endothelial cells, and thinner walls. Although the vessels retained a back to back pattern in most of the lesion, the tumours were unencapsulated and at the periphery the vessels intermixed with the subcutaneous adipose tissue. Cutaneous adnexa, mainly sweat glands, appeared unaffected amidst the tumour vessels.

Abbreviations: $I H$, infantile haemangioma 


\begin{tabular}{|c|c|c|c|}
\hline Case & Age & Sex & Localisation \\
\hline $759 \mathrm{~B} 03$ & 2 years & M & Skin lower eyelid \\
\hline $48 \mathrm{H} 70$ & 2 months & $\mathrm{F}$ & Subcutaneous tissue calf \\
\hline $42 \mathrm{H} 7 \mathrm{I}$ & 2 years & M & Skin frontal region \\
\hline 933В83 & 6 months & M & Skin upper eyelid \\
\hline $440 B 87$ & Not known & $\mathrm{F}$ & Skin trunk dorsum \\
\hline $554 \mathrm{~B} 88$ & 9 months & M & Skin lumbar region \\
\hline 41542 & 1 year & $\mathrm{F}$ & Skin trunk dorsum \\
\hline $701 B 94$ & 7 years & M & Skin lower leg \\
\hline $911 \mathrm{~B} 94$ & 20 weeks of gestation & $\mathrm{F}$ & Placenta $^{3}$ \\
\hline $641 \mathrm{~B} 88974 \mathrm{~B} 89$ & 4 months & $\mathrm{F}$ & Placenta, ${ }^{4}$ Liver \\
\hline 1087B86 & 10 months & $\mathrm{F}$ & Breast \\
\hline 288B79 & 10 years & $\mathrm{F}$ & Submaxillary gland \\
\hline
\end{tabular}

Chorioangiomas presented the typical images of numerous capillaries with plump endothelial cells surrounded by one or more layers of pericytic cells in a myxoid stroma. The back to back arrangement of the capillaries varied from site to site.

Breast and submaxillary gland lesions showed similar features to skin IH, including and surrounding mamary ducts and salivary ducts, respectively. Particularly remarkable was the back to back pattern of the vessels (fig 1A, B).

The hepatic lesion contained several nodules that showed similar histological features to IH. The vessels were associated with portal areas and surrounded the biliary ducts. These portal areas were the only parts that displayed a few larger irregularly shaped vessels, probably dilated veins (fig 2 ).

The endothelial cells of all the IH and IH-like lesions were consistently positive for Glutl (fig 3A-D), whereas the pericytic cells were positive for $\alpha$ smooth muscle actin (fig 4A-C). Keratin immunostaining highlighted the ducts in all the lesions which were densly surrounded by the tumour vessels (fig $5 \mathrm{~A}-\mathrm{C}$ ).

The smooth muscle component of normal vessels was positive for $\alpha$ smooth muscle actin.

\section{DISCUSSION}

Confirming extensive studies already published, ${ }^{12}$ Glut l was present in the endothelial cells of all cases of cutaneous IH.

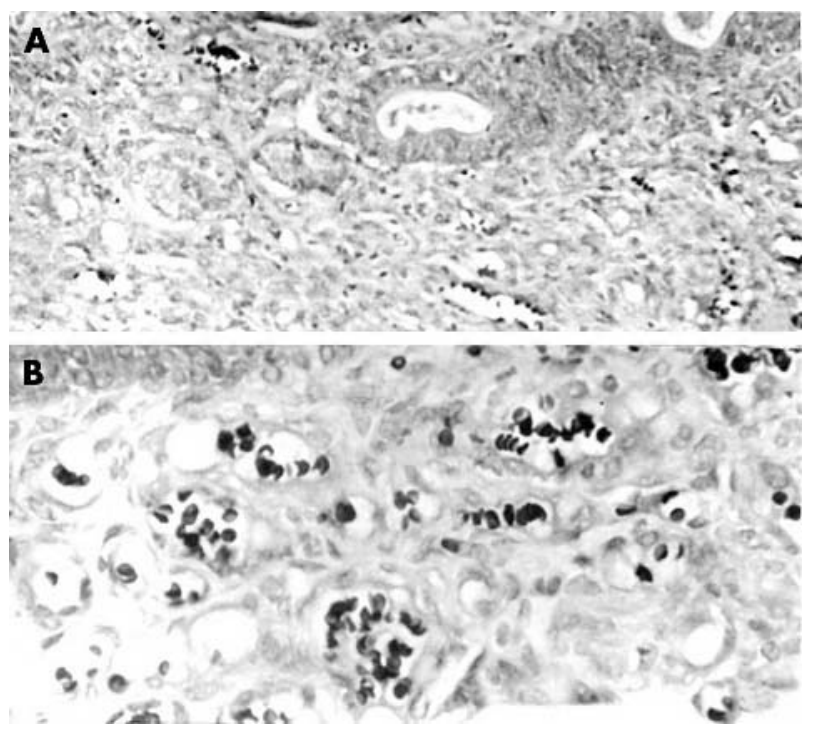

Figure 1 (A) Salivary gland and (B) mammary tissue involvement by infantile haemangioma. Extensive proliferation of capillaries with plump endothelial cells associated with ductal structures. Haematoxylin and eosin stain.
These also consistently contained smooth muscle actin positive pericytic cells.

Glutl positivity in the endothelial cells of chorioangiomas seems to be an expected and straightforward finding because capillaries of the placental villi normally express this marker (P North, H Kozakewich H. Society for Pediatrc Pathology. Washington, DC: Annual Meeting Workshop Handout, March 2003:22-3). ${ }^{1}$

As expected, Glutl showed positive immunoreactivity in red blood cells, basal keratinocytes, perineurium (fig 3A), apical brush border, basal membrane of the trophoblast (fig 3B), and microvascular endothelial cells of the fetal brain. Glutl immunoreactivity was not detected in the endothelial cells of adjacent normal tissues or in the vessels of the liver haemangioendotelioma.

Hepatic vascular lesions encompass the so called infantile haemangioendothelioma types I and II, cavernous haemangioma, epithelioid haemangioendothelioma, and angiosarcoma. ${ }^{5}$ In a recent review of a large series of vascular lesions of the liver, North and Kozakewich (P North, H Kozakewich H. Society for Pediatrc Pathology. Washington, DC: Annual Meeting Workshop Handout, March 2003:22-3) noticed that when liver haemangiomas were grouped as solitary or multiple lesions an unusual pattern emerged. Solitary lesions showed the histological features of classic infantile liver haemangioendothelioma, reproducing that of the so called rapidly involuting capillary haemangioma of the skin, whereas in multiple lesions the microscopic images of cutaneous IH were seen. This second pattern is the one recognised in our case, which presented several nodules.

$\mathrm{IH}$ in the region of the mammary gland is a rarely recognised lesion. Vascular tumours involving this gland include the so called perilobular haemangioma, atypical

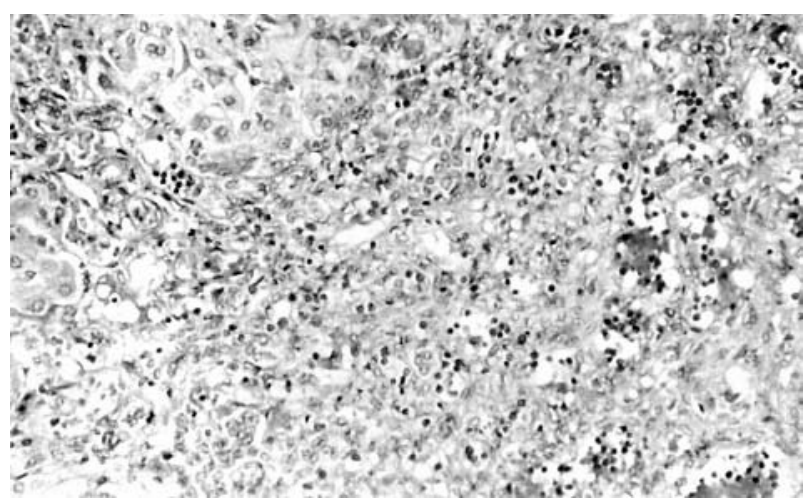

Figure 2 Liver tissue involvement by infantile haemangioma. Haematoxylin and eosin stain. 

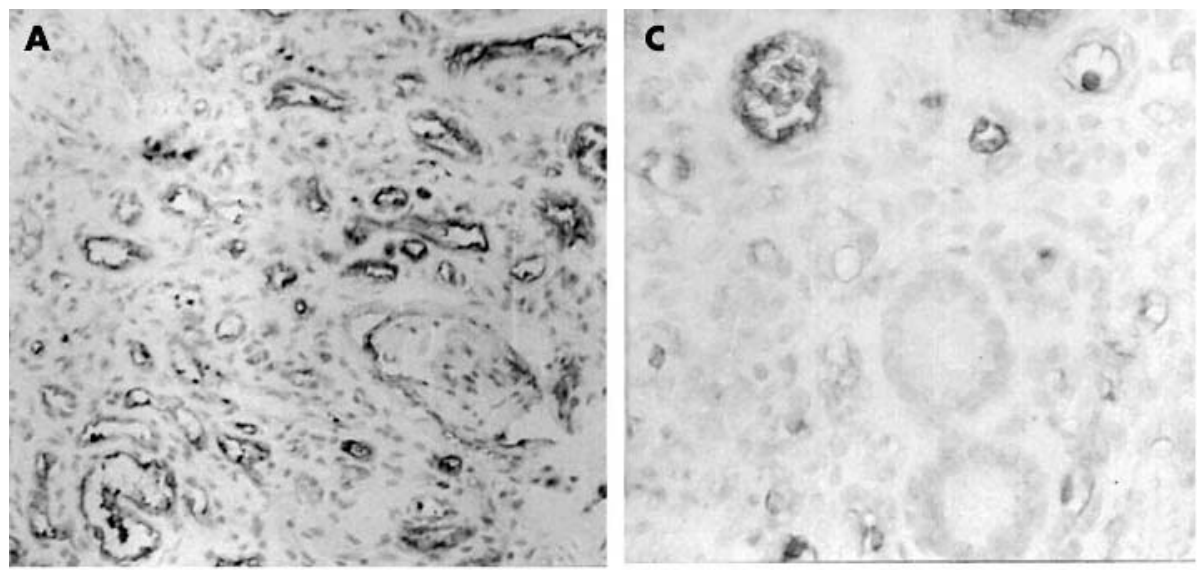

Figure 3 Glut1 positive endothelial cells in (A) skin, (B) placenta (chorioangioma), (C) salivary gland, and (D) liver capillary haemangioma. (A) Perineurial cells and (B) trophoblast, in addition to red blood cells, are also positive. Immunoperoxidase for Glut1.
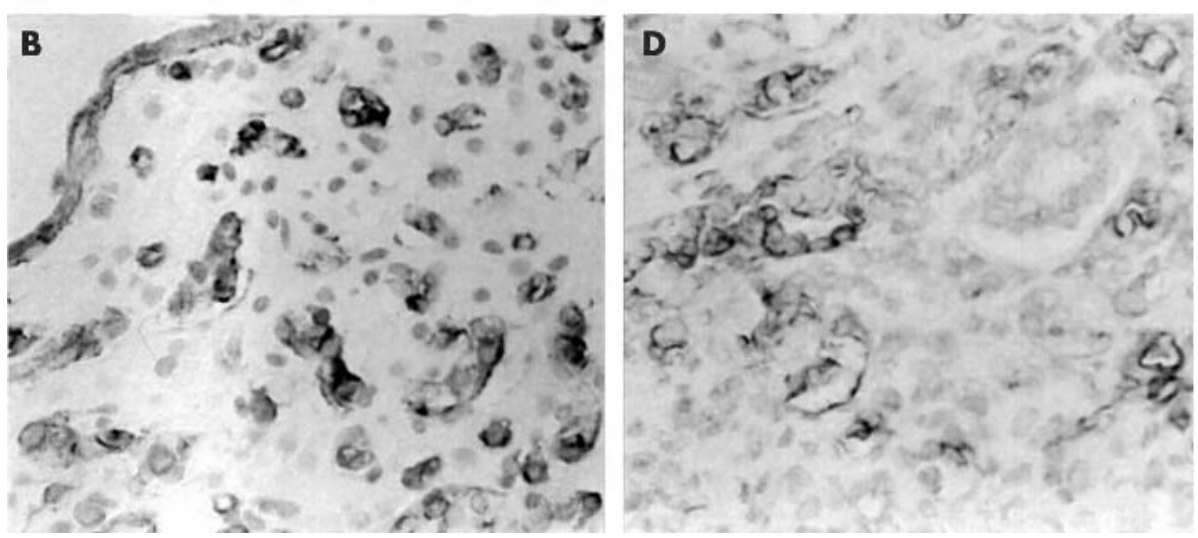
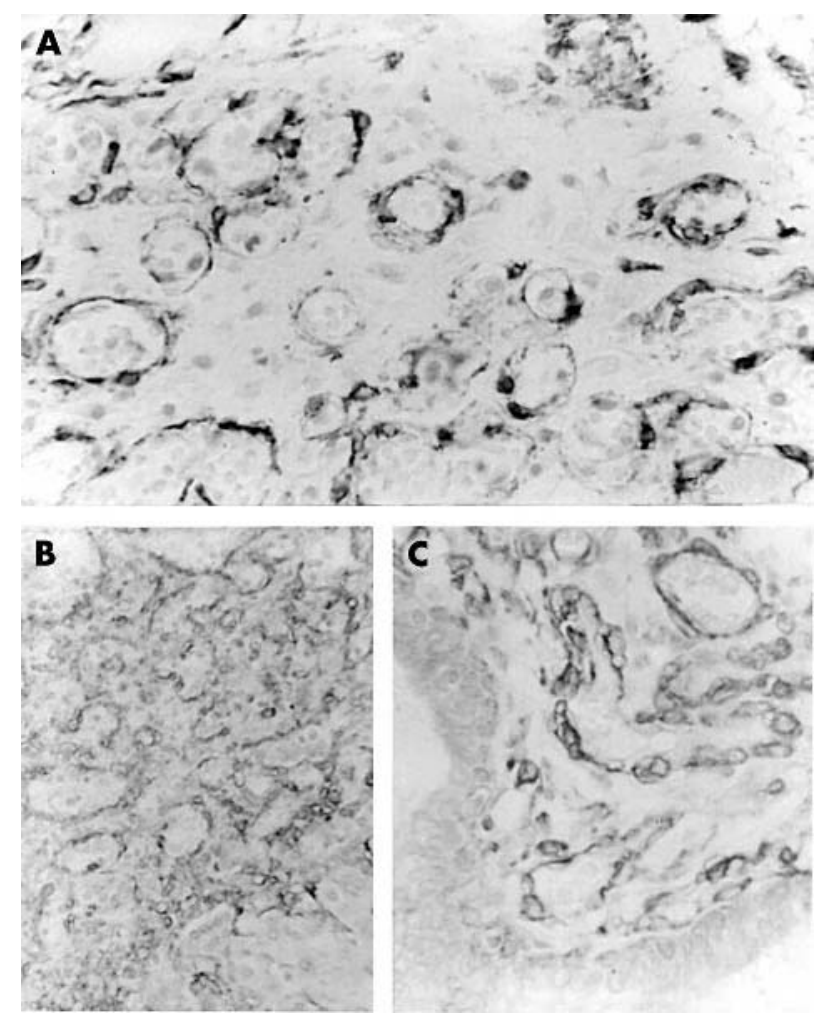

Figure 4 Pericytic component in infantile haemangioma as highlighted by $\alpha$ smooth muscle actin immunostaining in (A) chorioangioma, (B) liver, and (C) breast tissue. Immunoperoxidase for $\alpha$ smooth muscle actin. perilobular haemangioma, cavernous haemangioma, capillary haemangioma, and haemangioma with atypical features. $^{7}$ Rosen $^{8}$ investigated a series of nine non-parenchymal haemangiomas of mammary subcutaneous tissue, including one probably similar to ours, which he named juvenil haemangioma. Our case probably represents secondary involvement of ducts of the mammary gland (a modified sweat gland) by IH which developed in the subcutaneous adipose tissue of the breast.

With regard to the salivary gland occurrence of $\mathrm{IH}$, Childers and colleagues ${ }^{9}$ recently published their experience with 10 haemangiomas of the salivary gland, seven of which were found in the parotid gland of infants and were diagnosed as juvenile haemangioma. The authors stressed that the lobular arrangement was preserved, with acinar effacement and retention of nerves and ductal structures. One of their cases and another referred from the literature were associated with cytomegalovirus infection of the ductal epithelium. These cases fit with the features of our cases in the submaxillary gland.

One of the components of the vessels in $\mathrm{IH}$, whatever its site-skin, placenta, liver, breast, or salivary gland-is the pericytic cells. This is a consistent finding, which seems to be related to the progressive maturation of the endothelial cells and formation of small vessels. Hence, IH appears to contain two types of vasoformative cells undergoing divergent differentiation in an organoid vascular pattern, which probably reproduce large villous vessels rather than placental capillaries. An unusual condition associating both cells is present in the placenta, namely chorioangiomatosis. ${ }^{10}$ This should be distinguished from chorioangiosis and chorioangioma, which are related but different lesions. Chorioangiomatosis is characterised by increased numbers of vessels in the villi, which are made up of endothelial and 

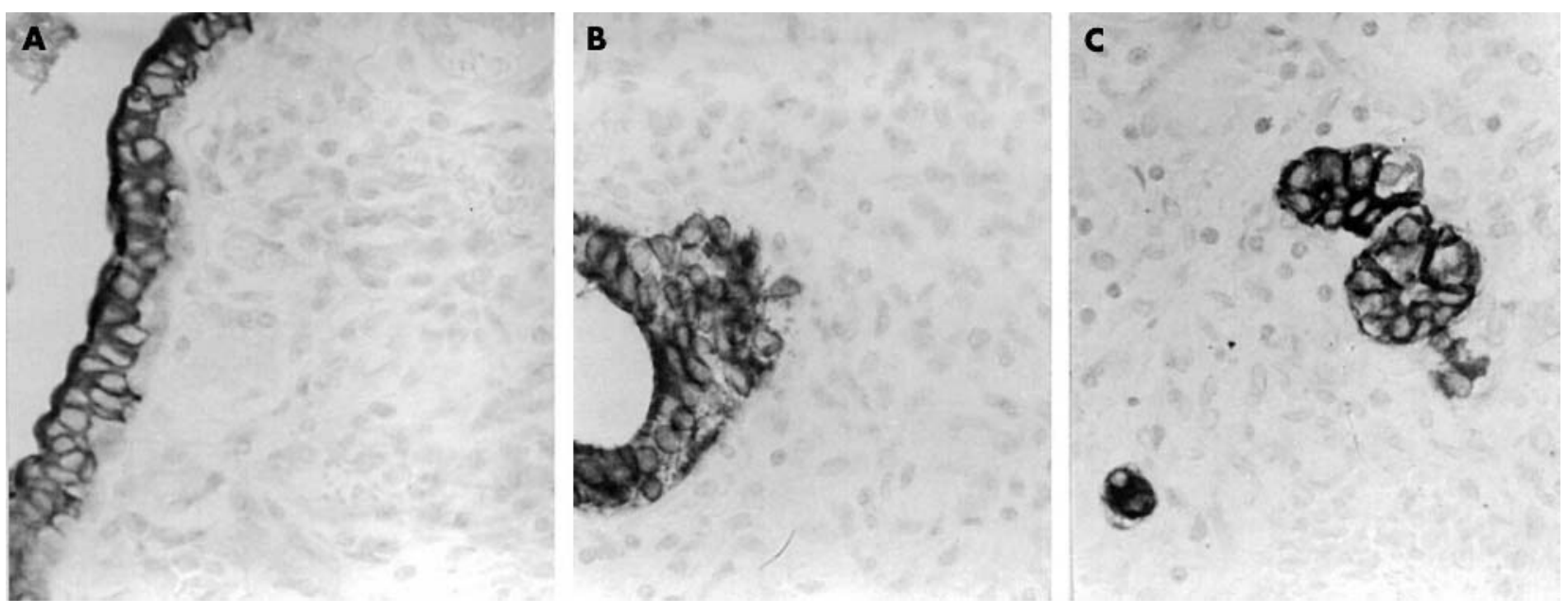

Figure 5 Keratin immunostaining was positive in the ductal epithelium in (A) mammary gland, (B) salivary gland, and (C) liver tissue involved by infantile haemangioma. Immunoperoxidase for keratin (AE1/AE3).

smooth muscle pericytic cells, presenting as focal, segmental, and/or diffuse multifocal subgroups. Chorioangioma is associated with an increased risk of extreme prematurity, congenital malformations, intrauterine growth retardation, delayed villous maturation, avascular villi, and placentomegaly. Placental chorioangiosis is not associated with smooth muscle pericytic cells.

"The association of multifocal infantile haemangioma with Beckwith-Wiedemann syndrome, coupled with data from the literature, points to the IGF2 gene and its product as the possible underlying molecular alteration in the genesis of this tumour"

Multiple chorioangiomas and multiple Glutl positive liver $\mathrm{IH}$, as found in our cases of Beckwith-Wiedemann syndrome, ${ }^{34}$ may be a key to the genetic changes related to the development of this tumour. In this sense, insulin growth factor 2 (IGF2) could be the link. Upregulation of the IGF2 gene (at 11p15), either directly or indirectly, appears to be related to the overgrowth tumours presenting in the syndrome. ${ }^{11}$ In addition, Ritter and colleagues ${ }^{12}$ have recently reported greatly increased expression of IGF2 mRNA and protein in the proliferative phase of IH, suggesting that IGF2 could be a regulator of haemangioma proliferation, particularly in view of its known mitogenic and apoptosis supressor activities.

Two recently recognised types of congenital haemangioma, known as non-involuting congenital haemangioma and rapidly involuting congenital haemangioma, are different from the Glutl positive IH of the skin. All the cases reported in this paper belong to the latter type. ${ }^{13}{ }^{14}$

In summary, $\mathrm{IH}$ is made up of a combined proliferation of Glutl positive endothelial cells and $\alpha$ smooth muscle actin positive pericytic cells, and represents a peculiar entity. IH can present at sites other than the originally recognised skin localisation, often reproducing the vessels of placental chorioangiomatosis and small arterioles of the placental villi. The association of multifocal IH with Beckwith-Wiedemann syndrome, coupled with data from the literature, points to the IGF2 gene and its product, the IGF2 protein, as the possible underlying molecular alteration in the genesis of this tumour.

\section{Authors' affiliations}

R M Drut, R Drut, Department of Pathology, Hospital de Niños "Superiora Sor María Ludovica", 1900, La Plata, Argentina

\section{REFERENCES}

1 North PE, Waner M, Mizeracki A, et al. GLUT1: a newly discovered immunohistochemical marker for juvenile hemangiomas. Hum Pathol 2000;31:11-22.

2 North PE, Waner M, Mizeracki A, et al. A unique microvascular phenotype shared by juvenile hemangiomas and human placenta. Arch Dermatol 2001;137:1-12.

3 Drut RM, Drut R. Nonimmune fetal hydrops and placentomegaly: diagnosis of familial Wiedemann-Beckwith syndrome with trisomy $11 \mathrm{p} 15$ using FISH. Am J Med Genet 1996;62:145-9.

4 Drut R, Drut RM, Toulouse JC. Hepatic hemangioendotheliomas, placental chorioangiomas, and dysmorphic kidneys in Beckwith-Wiedemann syndome. Pediatr Pathol 1992;12:197-203.

5 Ishak KG, Goodman ZD, Stocker JT. Tumors of the liver and intrahepatic bile ducts. Atlas of tumor pathology, 3rd series, Fascicle 31. Washington DC: AFIP, 2001

6 Patterson K. Liver tumors and tumorlike masses. In: Parham DM, ed. Pediatric neoplasia: morphology and biology. Philadelphia: Lippincott-Raven Publishers, 1996:331-61.

7 Rosen PP, Oberman HA. Tumors of the mammary gland. Atlas of tumor pathology, 3rd series, Fascicle 7. Washington DC: AFIP, 1992.

8 Rosen PP. Vascular tumors of the breast. V. Nonparenchymal hemangiomas of mammary subcutaneous tissues. Am J Surg Pathol 1985;9:723-9.

9 Childers ELB, Furlong MA, Fanburg-Smith JC. Hemangioma of the salivary gland: a study of ten cases of a rarely biopsed/excised lesion. Ann Diagn Pathol 2002;6:339-44.

10 Ogino S, Redline RW. Villous capillary lesions of the placenta: distinction between chorioangioma, chorioangiomatosis, and chorioangiosis. Hum Pathol 2000;31:945-54.

11 DeBaun MR, Niemitz EL, McNeil E, et al. Epigenetic alterations of $\mathrm{H} 19$ and LIT1 distinguish patients with Beckwith-Wiedemann syndrome with cancer and birth defects. Am J Hum Genet 2002;70:604-11.

12 Ritter MR, Dorrell MI, Edmonds J, et al. Insulin-like growth factor 2 and potential regulators of hemangioma growth and involution identified by largescale expression analysis. Proc Natl Acad Sci U S A 2002;99:7455-60.

13 Enjolras O, Mulliken JB, Boon LM, et al. Noninvoluting congenital hemangioma: a rare cutaneous vascular anomaly. Plast Reconstr Surg $2001 ; 107: 1647-54$

14 Berenguer B, Mulliken JB, Enjolras $O$, et al. Rapidly involuting congenital hemangioma: clinical and histopathologic features. Pediatr Dev Pathol 2003;6:495-510. 